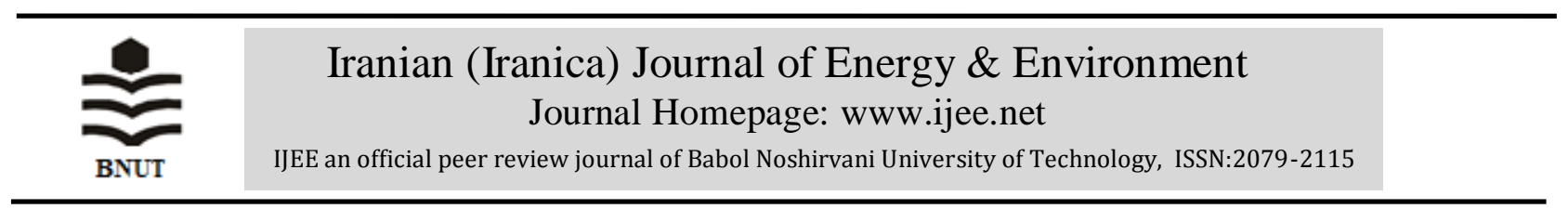

\title{
Role of Nanoparticles as Performance and Emission Improver of Compression Ignition Engine Fuels: An Overview
}

\author{
A. Kumar Singh ${ }^{1 *}$, R. Patle ${ }^{2}$, M. Das ${ }^{1}$, R. Sanodiya ${ }^{1}$, N. M. Stanley ${ }^{1}$, P. Malkhani $^{1}$ \\ ${ }^{1}$ Division of Agricultural Engineering, Indian Agricultural Research Institute, Pusa campus, New Delhi, India \\ ${ }^{2}$ Central Institute of Agricultural Engineering, Bhopal, India
}

\section{$P A P E R \quad I N F O$}

\section{Paper history:}

Received 02 May 2019

Accepted in revised form 24 June 2019

\section{Keywords:}

Compression Ignition Engine Fuels

Emission Characteristics

Nanoparticles

Performance

\section{$A B S T R A C A$}

Applications of nano-scaled energetic materials in diesel and diesel-biodiesel blends as catalytic agents have emerged contemporarily in pace to develop an efficient and eco-friendly alternative fuel for compression ignition (CI) engines. Inclusion of nanoparticles as additives for CI engine fuels promises as overall improver of engine performance and emission characteristics. However, simultaneous control on engine performance parameters and emission characteristics is usually difficult. Dispersion of nano-additives improves combustion efficiency by altering specific fuel properties of diesel. Average particle size of $40-50 \mathrm{~nm}$ facilitate greater surface-to-volume ratio, hence ensure more complete combustion through further chain reactions during combustion. Nanoparticles as catalytic agents in diesel and its proportionate blends have recently emerged as game changer but their potential is in-fact not fully explored for market acceptability. The following are the major challenges that are to be considered in future researches: (a) There is a need of onroad testing in real ambient conditions, (b) Effects of exhaust emission fuelled with nanocatalysts on human breathing, (c) Overall effects on diesel engines of agricultural tractors and other heavy earth moving machines which are designed for high load factors, and (d) Effects of such modified fuels on driving habits of consumers.

\section{INTRODUCTION}

Performance of diesel-powered vehicles is remarkable which made diesel engines (D-engines) became popular in past two decades. D-engines have shown their importance in all the major sectors, such as transportation, power industries, agricultural tractors and machines etc., owing to their fuel economy, reliability, sturdiness and rigidity [1]. In present, most of the medium and heavy-duty vehicles are powered by diesel fuel worldwide [2]. This is no-more surprise to state that the life of diesel fuel on earth is finite. Moreover, the usage of diesel has some devastating effects on our environment due to harmful exhaust emissions such as unburned hydrocarbon ( $\mathrm{HC})$, carbon-monoxide $(\mathrm{CO})$, sulphur oxides $\left(\mathrm{SO}_{\mathrm{x}}\right)$ and soot carbon $\left(\mathrm{C}_{\text {soot }}\right)$ [3]. Therefore, researches are more intended to develop alternative fuels these days.

Over the past three decades, several efforts have been made to develop alternative fuels from the plantation of agricultural based energy crops and other feed-stocks [1]. Biofuels produced from vegetable oils and non-edible plants has provided a vital alternative against diesel. Production of biodiesel and their proportionate blending with base fuel (diesel) have drawn researchers' attention in recent years [4] which has also proven successful to replace the dependency solely on diesel fuel at some extent. Liquid biofuels (e.g., bioethanol, biobuthanol and biodiesel) are capable of propelling both on-road and off-road transporting vehicles with considerable reduction of harmful emissions like $\mathrm{HC}$, $\mathrm{CO}, \mathrm{SO}_{\mathrm{x}}$ and $\mathrm{C}_{\text {soot }}$ [5]. However, usage of biodiesel has also exhibited lower engine performance, in terms of torque and power, due to its lower net calorific values as compared to conventional diesel [6]. Moreover, the use of biodiesel promotes nitrogen oxide $\left(\mathrm{NO}_{\mathrm{x}}\right)$ emission due to high peak temperature during the combustion process inside the engine cylinder (Figure 1) [7].

Xue et al. [8] suggested blending of biofuels with neat diesel in suitable proportion to improve performance and

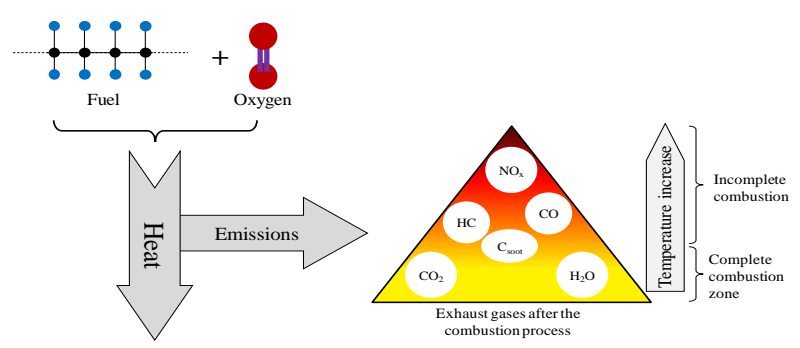

Figure 1. Formation of exhaust gases during combustion 
exhaust gas emissions from compression ignition (CI) engines which require slight modifications in engine designs. Abuzaid [7] studied the performance of a direct injection (DI), single-cylinder D-engine using water-in-diesel emulsion with $5,10,15$ and 20 water-to-diesel ratio and reported that the increase in brake thermal efficiency (BTE) of D-engine proportional to the concentration of water-diesel ratio. The improved overall emission characteristics were also achieved, including lower $\mathrm{NO}_{\mathrm{x}}$ emission, due to lower exhaust gas temperature [9]. Similarly, additives are also used with diesel and biodiesel blends which improve the ignition quality essentially by altering specific fuel properties. For example, Inclusion of organic based synthesized manganese (Mn) improve the cetane number, flash point and viscosity of diesel, hence ensures more complete ignition of diesel during combustion [10].

Ambrozik et al. [11] enlisted basic requirements of fuel additives which are as follows: (a) Catalysts added to fuels should reduce overall emission of harmful gases during the combustion. (b) Catalysts should maintain the chemical stability of fuel. (c) Catalysts use in fuel should not affect engine operating conditions. (d) Catalysts should improve specific fuel properties. Keskin et al. [12] investigated the effect of metal based-biodiesel blend B60 (containing 40 and $60 \%$ conventional diesel and tall oil, respectively) additives as combustion catalysts. A considerable improvement was reported in some specific fuel properties, such as flash point, pour point and viscosity, depending on the concentration of additives mixed with prepared fuel blend. Moreover, a significant decrease in $\mathrm{CO}$ and $\mathrm{NO}_{\mathrm{x}}$ emission with reduced smoke opacity.

In the pace of developing efficient and eco-friendly fuels for CI engines, applications of nano-scaled energetic materials in diesel and diesel-biodiesel blends as catalytic agents have also emerged contemporarily. Use of nanoparticles as fuel additives are in-fact unexplored today. However, many researchers have investigated performance and emissions characteristics of D-engines by using the inclusion of both individual nanoparticles and also with numerous combinations of more than one type of nanoparticles. Kao et al. [13] investigated change in combustion process due to inclusion of aqueous aluminium (Al) nano-additive, covered with oxide layers, in diesel fuel and reported an overall improvement in exhaust emission. Mehta et al. [14] formed oxides of $\mathrm{Al}, \mathrm{Fe}$ and $\mathrm{B}$ as nanocatalysts dispersed with neat diesel fuel and concluded that nanofuels reduced ignition delay with a significant increase and decrease of BTE and overall emissions, respectively. Prabu [15] investigated the effect of inclusion nanocatalysts of more than one type i.e., alumina $\left(\mathrm{Al}_{2} \mathrm{O}_{3}\right)$ and carbon nanotubes (CNTs), with neat diesel and diesel-biodiesel blends in different proportions. In addition to nanocatalysts based diesel fuel blends, researches have tested numerous combinations of hybrid fuels as summarised in Table 1.

\section{EFFECTS OF NANOCATALYSTS ON SPECIFIC FUEL PROPERTIES}

Determination of diesel fuel properties contributes a very crucial role to examine the acceptability of diesel in CI engines during combustion [16]. Cetane number $(\mathrm{CN})$ is an indicator of ignition delay (time between the fuel injection and the spontaneous ignition of fuel) of diesel [17]. CN value of a diesel fuel depends primarily on its chemical composition. In D-engine, the desirable $\mathrm{CN}$ value is established by the requirements of good ignition quality at light loads and low temperatures [18]. De et al. [19] observed that the presence of ethanol and ethyl ter-butyl ether (ETBE) significantly alters the characteristics of volatility and reduces the Cetane number, impairing the fuel's performance in engine tests.

Yang et al. [20] reported that emulsion fuels 10 and 15 (water-in-diesel, $10 \%$ and $15 \%$, respectively) exhibit higher viscosity index of $8.8 \mathrm{cSt}$ and $11.4 \mathrm{cSt}$ at $40^{\circ} \mathrm{C}$, respectively. Due to the same, engine power drops down significantly and consequently affects customers' driving habits. Use of nanocatalysts in emulsion fuel having $5 \%$ water displayed a significant decrease in kinematic viscosity of $7.6 \mathrm{cSt}$ at $40^{\circ} \mathrm{C}$. Viscosity of emulsion fuels is higher than pure diesel but drops down faster with an increase in temperature as compared to that of diesel. Basha et al. [21] observed an increase in viscosity of $5.36 \mathrm{cSt}$ in modified fuel blend consisting $\mathrm{JBD}, \mathrm{Al}_{2} \mathrm{O}_{3}$ and $\mathrm{CNT}$, as compared to pure JBD $(5.25 \mathrm{cSt})$.

Density is a significant property for diesel engines, which affects the performance characteristics of engines and the other many performance characteristics like higher heating value. Cetane number is correlated against density [ $\left.{ }^{r} 2-28\right]$. Furthermore, the amount of fuel in the fuel injection systems is measured volumetrically, and the changes in density affect the engine output power and fuel consumption [29, 30]. Table 2 has displayed variations in essential fuel properties due to the inclusion of nanocatalysts in different diesel and dieselbiodiesel fuel blends. Chief characteristics of nanocatalysts have improved oxidation intensity due to having higher surface-to-volume ratio. The dispersion of nanocatalysts in fuel/fuel blends improve combustion characteristics mainly due to better fuel atomisation and rapid evaporation, which allow more surface area of fuel to react with oxygen molecules [15].

\section{METHODS TO PREPARE NANOCATALYSTS MIXED FUEL BLENDS}

Generally, the preparation of nanocatalysts mixed fuel blends is a two step process: (a) treatment of nanoparticles, and (b) their dispersion into fuel blends. Kao et al. [13], at first step, made an attempt on nano-scaled $(40-60 \mathrm{~nm})$ aqueous alumina coated with thin oxide layer due to high oxidation activity of pure aluminum $(\mathrm{Al})$. In second step, the oxide coated nanocatalysts were dispersed in the diesel fuel with the aid of ultrasonicator. Studies have shown that water can react with nano-scaled 'Al' powder during combustion to generate hydrogen, hence increase the combustion heat of aqueous ' $\mathrm{Al}$ ' fuel. Hydrogen is clearly a promising alternative to hydrocarbon fossil fuels since it has higher energy efficiencies with lower emissions [31]. The catalytic activity of a metal-oxide catalyst $\mathrm{Fe} / \mathrm{Al}_{2} \mathrm{O}_{3}$ can cause water to yield hydrogen through decomposition [32]. 
TABLE 1. Summery of fuel hybrids prepared using nanocatalyst(s)

\begin{tabular}{|c|c|c|}
\hline \multirow{2}{*}{ Author (s) } & \multicolumn{2}{|r|}{ Fuel hybrids } \\
\hline & Notation & Composition \\
\hline \multirow{7}{*}{ Keskin et al. [12] } & B60 & $40 \%$ pure diesel and $60 \%$ biodiesel prepared from tall oil \\
\hline & $\mathrm{B} 60-4 \mathrm{Mg}$ & Magnesium $(\mathrm{Mg})$ with B60 @ $4 \mu \mathrm{mol} / \mathrm{L}$ \\
\hline & $\mathrm{B} 60-8 \mathrm{Mg}$ & 'Mg' with B60 fuel blend @ $8 \mu \mathrm{mol} / \mathrm{L}$ \\
\hline & $\mathrm{B} 60-12 \mathrm{Mg}$ & 'Mg' with B60 fuel blend @ $12 \mu \mathrm{mol} / \mathrm{L}$ \\
\hline & $\mathrm{B} 60-4 \mathrm{Mo}$ & Molybdenum (Mo) with B60 @ $4 \mu \mathrm{mol} / \mathrm{L}$ \\
\hline & $\mathrm{B} 60-8 \mathrm{Mo}$ & ‘Mo’ with B60 fuel blend @ $8 \mu \mathrm{mol} / \mathrm{L}$ \\
\hline & $\mathrm{B} 60-12 \mathrm{Mo}$ & ‘Mo' with B60 fuel blend @ $12 \mu \mathrm{mol} / \mathrm{L}$ \\
\hline \multirow{4}{*}{ Tewari et al. [33] } & Diesel & Pure diesel \\
\hline & MOME & Honge Oil Methyl Ester (biodiesel) \\
\hline & $\mathrm{HOME}+25 \mathrm{CNT}$ & $\begin{array}{l}\text { Carbon nanotubes (CNT) blended with HOME having concentration of } 25 \\
\text { ppm }\end{array}$ \\
\hline & $\mathrm{HOME}+50 \mathrm{CNT}$ & CNT blended with HOME having concentration of $50 \mathrm{ppm}$ \\
\hline \multirow{6}{*}{ Basha et al. [21] } & JBD & Pure Jatropha biodiesel \\
\hline & $\mathrm{JBD}+25 \mathrm{Al}_{2} \mathrm{O}_{3}$ & JBD with Alumina $\left(\mathrm{Al}_{2} \mathrm{O}_{3}\right)$ having concentration of $25 \mathrm{ppm}$ \\
\hline & $\mathrm{JBD}+50 \mathrm{Al}_{2} \mathrm{O}_{3}$ & JBD with $\mathrm{Al}_{2} \mathrm{O}_{3}$ having concentration of $50 \mathrm{ppm}$ \\
\hline & $\mathrm{JBD}+25 \mathrm{CNT}$ & JBD with carbon nanotubes $(\mathrm{CNT})$ having concentration of $25 \mathrm{ppm}$ \\
\hline & $\mathrm{JBD}+50 \mathrm{CNT}$ & JBD with $\mathrm{Al}_{2} \mathrm{O}_{3}$ having concentration of $25 \mathrm{ppm}$ \\
\hline & $\mathrm{JBD}+25 \mathrm{Al}_{2} \mathrm{O}_{3}+25 \mathrm{CNT}$ & JBD with $\mathrm{Al}_{2} \mathrm{O}_{3}$ and $\mathrm{CNT}$ having concentration of $25 \mathrm{ppm}$ of each \\
\hline \multirow{5}{*}{ Basha et al. [21] } & JME & Pure Jatropha methyl esters \\
\hline & JME2S5W & $93 \% \mathrm{JME}+2 \%$ surfactant $+5 \%$ water \\
\hline & JME2S5W25CNT & $93 \% \mathrm{JME}+2 \%$ surfactant $+5 \%$ water $+25 \mathrm{ppm} \mathrm{CNT}$ \\
\hline & JME2S5W50CNT & $93 \% \mathrm{JME}+2 \%$ surfactant $+5 \%$ water $+50 \mathrm{ppm} \mathrm{CNT}$ \\
\hline & JME2S5W100CNT & $93 \% \mathrm{JME}+2 \%$ surfactant $+5 \%$ water $+100 \mathrm{ppm} \mathrm{CNT}$ \\
\hline \multirow{8}{*}{$\begin{array}{l}\text { Mirzajanzadeh et } \\
\text { al. [34] }\end{array}$} & B5 & $95 \%$ pure diesel and $5 \%$ biodiesel prepared from waste cooking oil (WCO) \\
\hline & B20 & $80 \%$ pure diesel and $20 \%$ WCO-biodiesel \\
\hline & B5+(CeO $2-\mathrm{MWNTs}) @ 30$ ppm & $\begin{array}{l}\text { B5 with hybrid of cerium oxide }\left(\mathrm{CeO}_{2}\right) \text { nanoparticles and multi-walled } \\
\text { carbon nanotubes (MWNTs) having concentration of } 30 \mathrm{ppm}\end{array}$ \\
\hline & $\mathrm{B} 5+\left(\mathrm{CeO}_{2}-\mathrm{MWNTs}\right) @ 60$ ppm & B5 hybrid of $\left(\mathrm{CeO}_{2}+\mathrm{MWNTs}\right)$ having concentration of $60 \mathrm{ppm}$ \\
\hline & B5+(CeO2-MWNTs) @ 90 ppm & B5 with hybrid of $\left(\mathrm{CeO}_{2}+\mathrm{MWNTs}\right)$ having concentration of $90 \mathrm{ppm}$ \\
\hline & $\mathrm{B} 20+\left(\mathrm{CeO}_{2}-\mathrm{MWNTs}\right) @ 30$ ppm & B20 with hybrid of $\left(\mathrm{CeO}_{2}+\mathrm{MWNTs}\right)$ having concentration of $30 \mathrm{ppm}$ \\
\hline & $\mathrm{B} 20+\left(\mathrm{CeO}_{2}-\mathrm{MWNTs}\right) @ 60$ ppm & B20 with hybrid of $\left(\mathrm{CeO}_{2}+\mathrm{MWNTs}\right)$ having concentration of $60 \mathrm{ppm}$ \\
\hline & $\mathrm{B} 20+\left(\mathrm{CeO}_{2}-\mathrm{MWNTs}\right) @ 90 \mathrm{ppm}$ & B20 with hybrid of $\left(\mathrm{CeO}_{2}+\mathrm{MWNTs}\right)$ having concentration of $90 \mathrm{ppm}$ \\
\hline
\end{tabular}

Soybean biodiesel

Shaffi et al. [35] B20 (soybean)

Pure biodiesel made of soybean

Diesel and soybean biodiesel in the ratio of $4: 1$

D80SBD15E4S $1+\mathrm{Al}_{2} \mathrm{O}_{3}$

\begin{tabular}{|c|c|c|}
\hline & - & $\mathrm{Al}_{2} \mathrm{O}_{3}$ having concentration of $100 \mathrm{mg} / \mathrm{L}$ \\
\hline \multirow{5}{*}{ Aalam et al. [36] } & Neat diesel & $100 \%$ pure conventional diesel fuel \\
\hline & Mahua Methyl Ester (MME) & $100 \%$ biodiesel prepared by vegetable oil \\
\hline & MME20 & Blend of $80 \%$ pure diesel and 20\% MME oil (by volume) \\
\hline & MME20 + ANP50 & \\
\hline & MME20 + ANP100 & MME20 with 100 ppm of aluminum oxide nanoparticles \\
\hline \multirow{5}{*}{ Prabu [15] } & Diesel & Pure diesel fuel \\
\hline & B100 (Jatropha) & Pure Jatropha biodiesel \\
\hline & B20 & Fuel blends containing $20 \%$ biodiesel and $80 \%$ diesel by volume \\
\hline & B100A30C30 & Fuel blends containing $100 \%$ biodiesel, $30 \mathrm{ppm} \mathrm{Al}_{2} \mathrm{O}_{3}$ and $30 \mathrm{ppm} \mathrm{CeO}_{2}$ \\
\hline & B20A30C30 & Fuel blends containing $20 \%$ biodiesel, $30 \mathrm{ppm} \mathrm{Al}_{2} \mathrm{O}_{3}$ and $30 \mathrm{ppm} \mathrm{CeO}_{2}$ \\
\hline
\end{tabular}


TABLE 2. Changes in fuel properties and performance and emission parameters due to inclusion of nanocatalyst(s)

\begin{tabular}{|c|c|c|c|c|c|c|c|c|c|}
\hline \multirow[b]{2}{*}{$\begin{array}{l}\text { Nanocatalyst(s) based fuel } \\
\text { blends }\end{array}$} & \multicolumn{5}{|c|}{ Fuel properties } & \multicolumn{4}{|c|}{ Performance and emission } \\
\hline & $\begin{array}{l}\text { Cetane } \\
\text { No. }\end{array}$ & $\begin{array}{c}\text { Kinematic } \\
\text { viscosity at } 40 \\
{ }^{\circ} \mathrm{C}, \mathrm{cSt}\end{array}$ & $\begin{array}{c}\text { Flash } \\
\text { point, }{ }^{\circ} \mathrm{C}\end{array}$ & $\begin{array}{l}\text { Density, } \\
\mathrm{kg} / \mathrm{m}^{3}\end{array}$ & $\begin{array}{c}\text { Calorific } \\
\text { value, } \mathbf{M J} \mathbf{k g}^{-1}\end{array}$ & BTE, & $\begin{array}{l}\text { bsfe, } \mathbf{k g} \\
\mathbf{k W}^{-1} \mathbf{h}^{-1}\end{array}$ & $\begin{array}{l}\text { HC, } \\
\text { ppm }\end{array}$ & $\begin{array}{l}\text { NO }_{x}, \\
\text { ppm }\end{array}$ \\
\hline \multicolumn{10}{|l|}{ Basha et al. [21] } \\
\hline JBD & 53 & 5.25 & 85 & 895 & 38.88 & 24.9 & 0.37 & 60 & 1282 \\
\hline $\mathrm{JBD}+25 \mathrm{Al}_{2} \mathrm{O}_{3}$ & 54 & 5.31 & 84 & 896 & 39.22 & & & & \\
\hline $\mathrm{JBD}+50 \mathrm{Al}_{2} \mathrm{O}_{3}$ & 56 & 5.35 & 82 & 897 & 39.53 & 27.9 & 0.32 & 52 & 1015 \\
\hline $\mathrm{JBD}+25 \mathrm{CNT}$ & 55 & 5.29 & 83 & 895.5 & 39.5 & & & & \\
\hline $\mathrm{JBD}+50 \mathrm{CNT}$ & 57 & 5.33 & 81 & 897.9 & 39.78 & 27.1 & 0.33 & 49 & 1001 \\
\hline $\mathrm{JBD}+25 \mathrm{Al}_{2} \mathrm{O}_{3}+25 \mathrm{CNT}$ & 57 & 5.36 & 81 & 895.2 & 39.99 & 28.9 & 0.31 & 46 & 985 \\
\hline \multicolumn{10}{|l|}{ Tewari et al. [33] } \\
\hline Diesel & - & 2.3 & 56 & 840 & 43 & 28 & - & 32 & 800 \\
\hline HOME & - & 5.6 & 170 & 880 & 36.016 & 23 & - & 82 & 580 \\
\hline $\mathrm{HOME}+25 \mathrm{CNT}$ & - & 5.7 & 166 & 898 & 34.56 & 24 & - & 70 & 600 \\
\hline $\mathrm{HOME}+50 \mathrm{CNT}$ & - & 5.8 & 164 & 900 & 35.10 & 25 & - & 58 & 750 \\
\hline \multicolumn{10}{|l|}{ Basha et al. [21] } \\
\hline JME & 53 & 5.05 & 85 & 895 & 38.88 & 24.80 & & 59 & 1282 \\
\hline JME2S5W & 51 & 5.4 & 140 & 899.8 & 37.05 & 26.34 & 0.346 & 63 & 1001 \\
\hline JME2S5W25CNT & 54 & 5.43 & 130 & 897.2 & 37.28 & 27.89 & 0.315 & 60 & 973 \\
\hline JME2S5W50CNT & 55 & 5.76 & 125 & 897.8 & 37.35 & 28.13 & 0.308 & 60 & 961 \\
\hline JME2S5W100CNT & 56 & 5.91 & 122 & 899.4 & 37.85 & 28.45 & 0.301 & 57 & 910 \\
\hline \multicolumn{10}{|l|}{ Shaffi et al. [35] } \\
\hline Diesel & 57 & 2.61 & - & 825 & 44.7 & - & 0.349 & - & 1792 \\
\hline Soybean biodiesel & 49 & 4.78 & - & 865 & 41.2 & - & & & \\
\hline B20 (soybean) & 42 & 3.7 & - & 847 & 43 & - & 0.312 & - & 1921 \\
\hline $\mathrm{D} 80 \mathrm{SBD} 15 \mathrm{E} 4 \mathrm{~S} 1+\mathrm{Al}_{2} \mathrm{O}_{3}$ & 52 & 3.37 & - & 840 & 42.59 & - & 0.309 & - & 1971 \\
\hline \multicolumn{10}{|l|}{ Aalam et al. [36] } \\
\hline Neat diesel & 47 & 3 & 56 & 815 & 42 & - & - & - & - \\
\hline Mahua Methyl Ester (MME) & 56 & 3.9 & 136 & 869 & 39.95 & - & - & - & - \\
\hline MME20 & 49 & 3.4 & 76 & 826 & 41.62 & - & - & - & - \\
\hline MME20 + ANP50 & 49.5 & 3.37 & 71 & 827.5 & 41.67 & - & - & - & - \\
\hline MME20 + ANP100 & 51 & 3.33 & 65 & 829 & 41.69 & - & - & - & - \\
\hline \multicolumn{10}{|l|}{ Prabu [15] } \\
\hline Diesel & - & 2.20 & 48 & 835 & 42.3 & 32.3 & - & 25 & 1320 \\
\hline B100 & - & 4.10 & 85 & 873 & 39.5 & 28.5 & - & 18 & 1390 \\
\hline $\mathrm{B} 20$ & - & 2.58 & 55 & 843 & 41.7 & 30.3 & - & 13 & 1300 \\
\hline B100A30C30 & - & 4.10 & 83 & 874 & 40.2 & 31 & - & 12 & 1208 \\
\hline B20A30C 30 & - & 2.59 & 52 & 844 & 42.2 & 32.5 & - & 10 & 978 \\
\hline
\end{tabular}

Yang et al. [20] prepared an emulsion fuel with diesel, water and water soluble oxygenated fuel additives, consisting glycerine and polyethoxy-ester, in the proportion of $82.5,5$ and $12.5 \%$, respectively. In order to tranquilise oil-water surface tension, surfactant (LP-9) was also added. The addition of surfactants can reduce the pooling of nanoparticles and their accumulation in nanoparticles as demonstrated by many studies [37]. Chaichan et al. [17] prepared a nanosoluble diesel emulsion by adding distilled water containing nanoparticles and mixed with diesel by using ultra sonic shaker one hour to ensure the complete mixing of water with diesel fuel. Shaffi et al. [35] attempted two-step method to 
prepare modified fuel blends. First, $100 \mathrm{mg}$ of $\mathrm{Al}_{2} \mathrm{O}_{3}$ were mixed in $99.9 \%$ pure ethanol and then, mixed with the dieselsoybean biodiesel blend. The phase separation is prevented by the addition of iso-propanol as a surfactant. The fuel sample was transferred to the ultrasonicator to intensively disperse the particles and to reduce their agglomeration.

Sarvestany et al. [31] prepared emulsified diesel fuels of ferrofluid which consist $\mathrm{Fe}_{3} \mathrm{O}_{4}$ nanoparticles dispersed in diesel having concentration of 0.4 and $0.8 \%$ by volume, respectively. One of the most important features of ferrofluids is their stability, which means that particles in the fluid do not agglomerate and phase-separate, even in the presence of strong magnetic fields [32]. Moreover, nanoparticles have higher suspension period of more than one week when dispersed into test fuels [26]. Mirzajanzadeh et al. [34] prepared a novel fuel blend by synthesising $\mathrm{CeO}_{2}$ and carbon nanotubes (multi-walled) and dispersed into biodiesel prepared by waste cooking oil by means of ultrasonic bath.

\section{EFFECTS OF NANOCATALYSTS BASED FUELS ON ENGINE PERFORMANCE}

Inclusion of nanoparticles in diesel, biodiesel and dieselbiodiesel blends have influenced the overall engine performance. Keskin et al. [12] observed non-significant improvement in performance with slightly less specific fuel consumption of single cylinder diesel engine when fuelled with metal based nanocatalysts. Basha et al. [21] observed higher BTE in nanoparticles blended JBD fuel at all the loads when tested with single cylinder $4.4 \mathrm{~kW}$ of air-cooled stationary engine. The lower brake specific fuel consumption (BSFC) was probably attributed to catalytic effects of Aloxide and CNT nanoparticles due to their enhanced surfacearea/volume ratio. Nanocatalysts as fuel additives help to boost combustion efficiency of diesel engine by shortening the ignition delay [23]. Tewari et al. [33] studied variations in BTE due to the inclusion of multi-walled CNT nanocatalysts, under different concentrations of 25 and $50 \mathrm{ppm}$, mixed in indigenously prepared biodiesel (HOME). Variations in BTE were found proportional to the concentration of CNT added to the fuel, greater for $50 \mathrm{ppm}$ concentration as compared to either 25 ppm or without inclusion of CNT.

Basha et al. [21] investigated performance of single cylinder $4.4 \mathrm{~kW}$ engine due to inclusion of nanocatalysts consisting both $\mathrm{Al}_{2} \mathrm{O}_{3}$ and CNT. Reduction in peak pressure, heat release rate and ignition delay was observed due to the inclusion of nanocatalysts $\left(\mathrm{Al}_{2} \mathrm{O}_{3}+\mathrm{CNT}\right)$ in pure JBD. BTE and $\mathrm{BSFC}$ were found maximum and minimum, respectively, when both $\mathrm{Al}_{2} \mathrm{O}_{3}$ and $\mathrm{CNT}$ nanocatalysts were dispersed in JBD. Mirzajanzadeh et al. [34] investigated the effects on engine power and torque due to inclusion of a hybrid nanocatalyst containing $\mathrm{CeO}_{2}$ on amide-functionalized MWNTs with two types of diesel biodiesel blends (B5 and B20) at three concentrations (30,60 and $90 \mathrm{ppm})$. Under constant speed and full load conditions, engine power and torque were increased with increasing the concentration of hybrid nanocatalysts in B5 and B20, respectively. Prabu [15] reported a significant improvement of $12 \%$ in BTE of diesel engine for the nanoparticles dispersed test fuel (B20A30C30) as compared to B100.

\section{EFFECTS OF NANOCATALYSTS BASED FUELS ON EMISSIONS}

Generally, engine emissions are divided into two categories: emissions produced as results of high flame temperature in chamber like $\mathrm{NO}_{\mathrm{x}}$ and emissions produced resulting from incomplete combustion of fuel and lower flame temperature like $\mathrm{HC}$ and $\mathrm{CO}_{2}$. Simultaneous control of the pollutants is difficult since different pollutants form at different temperatures [23]. $\mathrm{CO}$ is produced as a result of incomplete combustion of air-fuel mixture, low combustion cycle time in the engine or lower temperature of the combustion chamber [34]. Figure 2 has summarized the effects on exhaust gas emissions with and without the inclusion of nano-additives with fuel during combustion inside the engine cylinder. Fuel usually burns locally instead propagating uniformly into the cylinder, chiefly due to poor atomisation of fuel. Inclusion of nanoparticles in fuel spreads in the form of millions of clusters uniformly and facilitates more complete burning of fuel, hence reduces emission of harmful exhaust gases with improved combustion efficiency.

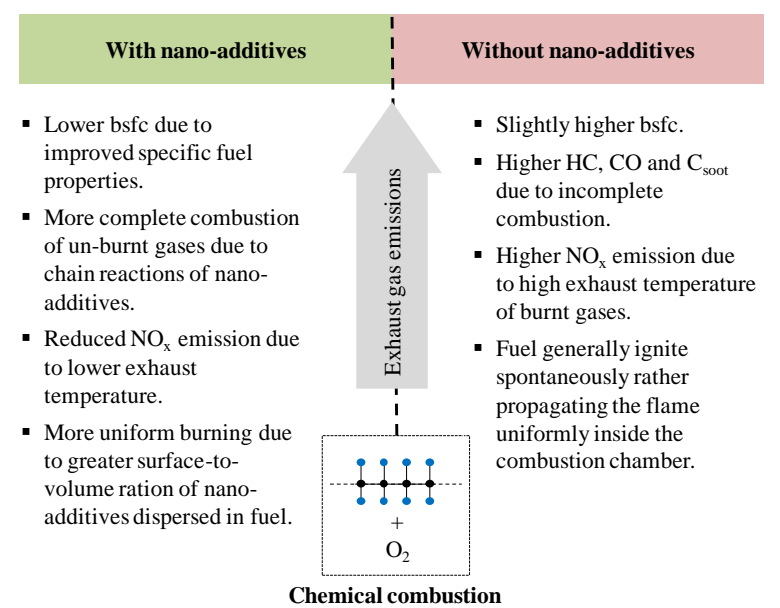

Figure 2. Effects on exhaust gas emissions (with and without the inclusion of nano-additives)

\section{CONCLUSION}

So far studies done by researchers all across the world, inclusion of nanoparticles as additives in diesel and dieselbiodiesel blends have shown significant improvement in $\mathrm{CI}$ engine performance with overall reduced emissions. Today, application of nanotechnology is expected to play a vital role in order to develop an innovative fuel hybrid for CI engines that may revolutionize the automobile sector worldwide. However, the development of such nanocatalyst(s) based CIengine fuel is still a matter of concern due to limited and not fully explored $\mathrm{R}$ and $\mathrm{D}$. The following are the major challenges that are to be considered in future researches: (a) There is a need of on-road testing in real ambient conditions, (b) Effects of exhaust emission fuelled with nanocatalysts on human breathing, (c) Overall effects on diesel engines of agricultural tractors and other heavy earth moving machines which are designed for high load factors, and (d) Effects of such modified fuels on driving habits of consumers. 


\section{REFERENCES}

1. Basha, J. S, and R. B. Anand. 2014. Performance, emission and combustion characteristics of a diesel engine using carbon nanotubes blended jatropha methyl ester emulsion. Alexandria Engineering Journal, 53(2): 259-273.

2. Li, C. H. 2011. Experimental study of nano-additives for biofuel combustion improvement. in: Proceedings of the ASME 2011 International Mechanical Engineering Congress \& Exposition, IMECE2011, Denver, Colorado, USA.

3. Choi, S. H, and O. H. Younhtaig. 2006. The emission effects by the use of biodiesel fuel. International Journal of Modern Physics, 20(25n27): 4481-4486.

4. Hasheminejad, M., Tabatabaei, M., Mansourpanah, Y, and A. Javani. 2011. Upstream and downstream strategies to economize biodiesel production. Bioresource Technology, 102(2): 461-468.

5. Kean, A. J., Sawyer, R. F., Robert, A, and R. A. Harley. 2000. A fuel-based assessment of off-road diesel engine emissions. Journal of the Air and Waste Management Association, 50(11): 1929-1939.

6. McCarthy P., P., Rasul, M. G, and S. Moazzem. 2011. Analysis and comparison of performance and emissions of an internal combustion engine fuelled with petroleum diesel and different bio-diesels. Fuel, 90(6): 2147-2157.

7. Abu-Zaid, M. 2004. Performance of single cylinder, direct injection diesel engine using water fuel emulsions. Energy Conversion and Management, 45(5): 697-705.

8. Xue, J., Grift, T. E, and A. C. Hansen. 2011. Effect of biodiesel on engine performances and emissions. Renewable and Sustainable Energy Reviews. 15(2): 1098-1116.

9. Alptekin, E, and M. Çanakçı. 2008. Determination of the density and the viscosities of biodiesel-diesel fuel blends. Renewable Energy, 33(12): 2623-2630

10. Enweremadu, C. C., Rutto, H. L, and J. T. Oladeji. 2011. Investigation of the relationship between some basic flow properties of shea butter biodiesel and their blends with diesel fuel. International Journal of Physics and Sciences, 6(4):758-767

11. Ambrozik, A, and Z. Chlopek. 2001. The catalytic limitation of PM formation in engines. The $6^{\text {th }}$ International Congress of the Engine Construction, Rybacie, Ukrania.

12. Keskin, A., Gürü, M, and D. Altıparmak. 2008. Influence of tall oil biodiesel with $\mathrm{Mg}$ and $\mathrm{Mo}$ based fuel additives on diesel engine performance and emission. Bioresource Technology, 99(14): 6434-6438.

13. Kao, M., Ting, C., Lin, B, and T. Tsung. 2008. Aqueous aluminum nanofluid combustion in diesel fuel. Journal of Testing and Evaluation. 36(2): 186-190.

14. Mehta, R. N., Chakraborty, M, and P. A. Parikh. 2014. Nanofuels: combustion, engine performance and emissions. Fuel, 120: 91-97.

15. Prabu, A. 2017. Nanoparticles as additive in biodiesel on the working characteristics of a DI diesel engine. Ain Shams Engineering Journal, 9(4): 2343-2349.
16. Berger, P., Adelman, N. B., Beckman, K. J., Campbell, D. J., Ellis, A. B, and G. C. Lisensky. 1999. Preparation and properties of an aqueous ferrofluid. Journal of Chemical Education, 76(7): 943-948.

17. Chaichan, M. T., Kadhum, A. H, and A. Al-Amierya. 2017. Novel technique for enhancement of diesel fuel: Impact of aqueous alumina nano-fluid on engine's performance and emissions. Case Studies in Thermal Engineering, 10: 611-620.

18. Clothier, P. Q. E., B. D. Aguda, A. Moise, and H. O. Pritchard. (1993). How do diesel-fuel ignition improvers work? Chemical Society Reviews, 22(2): 101-108.

19. De Menezes, E. W., R. Da Silva, R. Cataluña, and R. J. C. Ortega. (2006). Effect of ethers and ether/ethanol additives on the physicochemical properties of diesel fuel and on engine tests. Fuel, 85(5-6): 815-822.

20. Yang, W. M., An. H., Chou, K. J., Mohan, B., Sivasankarlingam, V., Raman, V., Maghboli, A, and J. Li. 2013. Impact of emulsion fuel with nano-organic additives on the performance of diesel engine. Applied Energy, 112: 1206-1212.

21. Basha, J. S, and R. B. Anand. 2013. The influence of nano additives blended biodiesel fuels on the working characteristics of a diesel engine. Journal of the Brazilian Society of Mechanical Sciences and Engineering, 35(3): 257-264.

22. Fahd, A. M., Wenming, Y., Lee P. S., Chou, S. K, and C. R. Yap. 2013. Experimental investigation of the performance and emission characteristics of direct injection diesel engine by water emulsion diesel under varying engine load condition. Applied Energy, 102(C): 1042-1049.

23. Grégoire-Padró, C. E, and F. Lau. 2000. Advances in Hydrogen Energy. Kluwer Academic/Plenum Publishers, New York.

24. Gülüm, M, and A. Bilgin. 2015. Density, flash point and heating value variations of corn oil biodiesel-diesel fuel blends. Fuel Processing Technologies, 134: 456-464.

25. Gürü, M., U. Karakaya, D. Altıparmak., A. Alıcılar. (2002). Improvement of Diesel fuel properties by using additives. Energy Conversion and Management, 43(8): 1021-1025.

26. Hill, F. J. and C. G. Schleyerback. (1977). Diesel fuel properties and engine performance, SAE paper 770316. Society of Automotive Engineers, Warrendale, PA.

27. Ichikawa, S. 1997. Photoelectrocatalytic production of hydrogen from natural seawater under sunlight. International Journal of Hydrogen Energy, 22(7): 675678.

28. Lenin, M. A., Swaminathan, M. R, and G. Kumaresan. 2013. Performance and emission characteristics of a DI diesel engine with a nanofuel additive. Fuel, 109: 362365.

29. Matthew, C., Schmitt, R. (2015). Diesel-powered Passenger Cars and Light Trucks: Fact Sheet. Bureau of Transportation Statistics (BTS).

30. Özgür, C, and E. Tosun. 2017. Prediction of density and kinematic viscosity of biodiesel by artificial neural networks. Energy Sources, Part A: Recovery, Utilization, and Environmental Effects, 39(10): 985-991. 
31. Sarvestany, N. S., Farzad, A., Bajestan, E. E, and M. Mir. 2014. Effects of magnetic nanofluid fuel combustion on the performance and emission characteristics. Journal of Dispersion Science and Technology, 35(12): 1745-1750.

32. Tesfa, B., Mishra, R., Gua, F, and N. Powles. 2010. Prediction models for density and viscosity of biodiesel and their effects on fuel supply system in CI engines. Renewable Energy, 35(12): 2752-2760.

33. Tewari, P., Doijode, E., Banapurmath, N. R, and V. S. Yaliwal. 2013. Experimental investigations on a diesel engine fuelled with multiwalled carbon nanotubes blended biodiesel fuels. International Journal of Emerging Technology and Advanced Engineering, 3(3): 72-76.

34. Mirzajanzadeh, M., Tabatabaei, M., Ardjmand, M., Rashidi, A., Ghobadian, B., Barkhi, M, and M. Pazouki.
2015. A novel soluble nano-catalysts in diesel-biodiesel fuel blends to improve diesel engines performance and reduce exhaust emissions. Fuel, 139: 374-382.

35. Shaffi, T, and R. Velraj. 2015. Influence of alumina nanoparticles, ethanol and isopropanol blend as additive with diesel-soybean biodiesel blend fuel: Combustion, engine performance and emissions. Renewable Energy, 80(C): 655-663.

36. Aalam, C. S, and C. G. Saravanan. 2017. Effects of nano metal oxide blended Mahua biodiesel on CRDI diesel engine. Ain Shams Engineering Journal, 8(4): 689-696.

37. Tock, R.W., Hernandez, A., Sanders, J. K, and D. J. Yang. 2013. Catalyst component for aviation and jet fuels. United States Patent, US 8,545,577. 